\title{
Exploring the Antiproliferative Mechanisms of Urtica dioica L. extract in Human Promyelocytic Leukemia Cell Line
}

\author{
İnsan Promiyelositik Lösemi Hücre Hattında Isırgan Ekstraktının Antiproliferatif \\ Mekanizmalarının Araştırılıması
}

\author{
Ebru TEMiz ${ }^{1}$ (D) , ismail KOYUNCU ${ }^{2} \mathbb{D}$, Khandakar A.S.M. Saadat DDS ${ }^{3}$ (D), \\ Özgür YÜKSEKDAĞ ${ }^{2} \mathbb{D}$, Yazan AWARD ${ }^{2} \mathbb{D}$
}

\begin{abstract}
${ }^{1}$ Medical Promotion and Marketing Program, Health Services Vocational School, Harran University; Department of Biochemistry, Medical Faculty, Harran University, Sanliurfa, TURKEY

2 Department of Medical Biochemistry, Faculty of Medicine, Harran University, Sanliurfa, TURKEY

${ }^{3}$ Department of Medical Biology, Faculty of Medicine, Institute of Health Sciences, Gaziantep University, Gaziantep, TURKEY
\end{abstract}

Background: Nature is a source of therapeutic compounds which have fewer side effects compared to synthetic drugs. Stinging Urtica dioica L. extract, widely-used in Anatolia, has a strong antiproliferative effect on many types of cancer. However, the underlying molecular mechanisms of this effect is still not known.

Materials and Methods: In this study, the interaction of Urtica dioica L. extract at different concentrations with apoptosis and autophagy pathways in the human promyelocytic cell line (HL-60) was studied to elucidate how it triggers the antiproliferative effects. In this context, firstly, the plant leaves were extracted in water with the Soxhlet extraction method. $\mathrm{HL}-60$ cells were incubated with the extract at different concentrations for 24 hours, and the activated antitumoral effect pathway was investigated with advanced following molecular tests: MTT staining, Nitric oxide (NO) level, Annexin- $V$ in flow cytometry, cell cycle, mitochondrial membrane potential measurement (MMP) and qPCR for evaluation of apoptosis and autophagy mediator genes.

Results: It was determined that cell proliferation was suppressed at a concentration of $100 \mu \mathrm{g} / \mathrm{mL}$ and cells were kept in G0/G1 phase, MMP was impaired in cells and the rate of apoptotic cells increased. These apoptotic markers were confirmed by statistically increased expression of apoptotic and autophagy genes and NO level.

Conclusions: Taken together, it is predicted that Urtica dioica L. water extract initiates apoptosis in HL-60 cells and could be promising compound candidate for cancer treatment.

Keywords: HL-60, Urtica dioica L., Cancer, Apoptosis, APL

öz.

Amaç: Doğa, sentetik ilaçlara kıyasla daha az yan etkiye sahip terapötik bileşiklerin kaynağıdır. Anadolu'da yaygın olarak kullanılan ısırgan otu özütü, birçok kanser türü üzerinde güçlü bir antiproliferatif etkiye sahiptir. Bununla birlikte, bu etkinin altında yatan moleküler mekanizmalar hala bilinmemektedir.

Materyal ve Metod: Bu çalışmada, insan promiyelositik hücre hattında (HL-60) farklı konsantrasyonlarda hazırlanan ısırgan ekstraktının apoptozis ve otofaji yolakları ile etkileşimi ve antiproliferatif etkileri incelenmiştir. Bu kapsamda öncelikle bitki yaprakları Soxhlet ekstraksiyon yöntemi ile suda ekstrakte edilmiştir. HL-60 hücreleri, 24 saat boyunca farklı konsantrasyonlarda ekstrakt ile inkübe edildi ve aktif anti-tümöral etki yolu, ileri moleküler testler ile araştııılı: MTT boyama, Nitrik oksit (NO) seviyesi, flow sitometride Annexin-V, hücre döngüsü, mitokondriyal zar potansiyeli ölçümü (MMP) ile apoptozis ve otofaji yolak genlerinin değerlendirilmesi için qPCR.

Bulgular: $100 \mu \mathrm{g} / \mathrm{mL}$ konsantrasyonda hücre proliferasyonunun baskılandığı ve hücrelerin G0/G1 fazında tutulduğu, hücrelerde MMP'nin bozulduğu ve apoptotik hücre yüzdesinin arttığı belirlendi. Bu apoptotik belirteçler, apoptotik ve otofaji genlerinin istatistiksel olarak artan ekspresyonu ve NO seviyesi ile doğrulandı.

Sonuç: Tüm sonuçlar birlikte ele alındığında, ısırgan su ekstraktının HL-60 hücrelerinde apoptozisi başlattığı ve kanser tedavisi için umut verici bitki adayı olabileceği tahmin edilmektedir.

Anahtar Kelimeler: HL-60, Urtica dioica L., Kanser, Apoptozis, APL
Corresponding Author / Sorumlu Yazar

Ebru TEMiz (Dr., Ph.D.)

Harran University

Faculty of Medicine,

Department of Medical Biochemistry.

Osmanbey Campus,

18th km on Sanliurfa-Mardin Highway, 63290 Haliliye, Şanliurfa. TURKEY

e-mail: ebrutemiz90@gmail.com

Received / Geliş tarihi: 20.10.2021

Accepted / Kabul tarihi: 26.11.2021

DOI: 10.35440/hutfd.1012538 


\section{Introduction}

Acute Promyelocytic Leukemia (APL) is a bone marrow malignancy characterized by an excess of immature cells called promyelocytes. APL, was developed as a result of the disruption of the gene encoding for retinoic acid alpha receptor on the 17. chromosome, and this chromosome exhibits unique clinical features which are totally different from the other types of cancer (1).

Although there are many types of leukemia, some of them are more common in children. Other types are generally seen in adults. APL constitutes 5-8\% of all acute myeloid leukemias (AML). Among the most recent treatment options, all-trans retinoic acid (ATRA) therapy and chemotherapy combinations are considered to be the most preferred approach, meanwhile a complete remission can be achieved in almost $90 \%$ of newly diagnosed APL patients (2).

APL is one type of cancer whose genetic and molecular activities have been well studied (3), however, most of the molecular and genetic mechanisms involved in the pathogenesis of APL are still unknown. Therefore, detailed molecular analyses of both the functional signaling pathways and the interaction of natural/synthetic agents with these signaling pathways can also play a substantial role in understanding the molecular etiology of the disease and developing new sophisticated therapeutic strategies. The main problems facing cancer therapies are that cancer cells can develop resistance to chemotherapy and other existing therapies which cause serious side effects. Therefore, the number of studies for investigating supportive and alternative drugs with less side effects, low cost and high cytotoxicity on cancer cells has been increased in recent years (4). The most popular agents in supportive and alternative drug development studies are obtained from medicinal plant extracts. Many studies have shown that herbs can reactivate blocked apoptotic pathways in cancer cells. It needs to be pointed that highly studied herbs are Urtica dioica $L$. plants $(5,6)$.

This plant has 40 species and about 500 subspecies, is endemic to Malaysia, India, America and tropical countries. However, it spreads less frequently in Europe and Africa. Although there are differences between the parts of the Urtica dioica L. plant but the main compounds that make up this extract are tannin, formic acid, phytosterin, iron and mucilage. It can be used use in the treatment of various diseases such as diabetes, atherosclerosis, cardiovascular disease, prostate cancer (7-10). There are three types of cell death pathways: apoptosis, necrosis, and autophagy. They play a large substantial role in eliminating abnormal cells in the tissue, keeping the cell number constant, regulating growth and eliciting the immune response. The reduction of apoptotic flow or the development of resistance plays an initiating role in cancer formation. therefore, new anti-tumor compounds must be specifically formed to target mediators that are located in the apoptotic pathway $(11,12)$. As we know, there are no studies showing the anti-tumors potential of the extract obtained from Urtica dioica L. plants in the HL-60 cell line. Therefore, in this study, it was aimed to elucidate the antiproliferative effects of Urtica dioica $L$. plants and it was supposed to have anti-proliferative effects in many types of cancer especially in the HL-60 cell line, this study was done to reveal their interaction with cell death pathway mediators.

\section{Materials and Methods Materials}

The cell-culture medium (DMEM: F-12), fetal bovine serum (FBS), streptomycin, dimethyl sulfoxide (DMSO), MTT and penicillin were purchased from Sigma (Sigma-Aldrich, USA). The culture plates were purchased from Nunc (Brand products, Denmark). ELISA kits were purchased from Nitric oxide (NO) (My BioSource, USA).

\section{Cell Culture}

The following cell lines purchased from ATCC and kept in liquid nitrogen were used for the study: HL-60 (CCL-240human leukemia cell line). The cell was cultured in DMEM: F-12 media supplemented with $10 \%$ Fetal Bovine Serum (FBS), $100 \mu \mathrm{g} / \mathrm{mL}$ streptomycin/100 IU/mL penicillin in incubators at $37^{\circ} \mathrm{C}$ under humid conditions containing $5 \% \mathrm{CO}_{2}$ and $95 \%$ air.

\section{Plant Extraction}

The stems and leaves of the plants to be used in the study were dried in $40^{\circ} \mathrm{C}$ incubator. After the dried plant samples were pulverized, $100 \mathrm{gr}$ was taken and extracted in polar solvent (water) using the Soxhlet extraction method. It was dried and lyophilized with the help of a rotary evaporator. $10 \mathrm{mg} / \mathrm{mL}$ stock was prepared from lyophilized plant extracts and used by dilution (DMSO was used>1/1000 as solvent).

\section{Cell Viability Assay}

The cytotoxicity of the extracts obtained from plant were assessed using the MTT (3-(4,5-Dimethylthiazol-2-yl)-2,5Diphenyltetrazolium Bromide) (Sigma-Aldrich, USA) assay. The cells were incubated in 24-well sterile plates for 24 hours with $1 \times 10^{5}$ cells per well. The media was removed and the Urtica dioica $L$. extracts were added at doses of 0,50 and $100 \mu \mathrm{g} / \mathrm{mL}$ subsequently, the media and the control (DMSO) were incubated for 24 hours and stained with MTT. Measurements in the luminescence mode were performed in a plate-reader (Thermo Scientific Multiskan GO, USA).

\section{Annexin V/PI Double Staining}

FITC Annexin V Apoptosis Detection Kit I (Cat No./ID:556547, BD, New Jersey, ABD) was used to detect the apoptosis of the HL-60 cells by flow cytometry pursuant to the manufacturer's instruction. According to the kit protocol, $5 \times 10^{6}$ cells were seeded in 6 well plates and incubated by applying DMSO and plant extract at dose of $100 \mu \mathrm{g} / \mathrm{ml}$. It was transferred as $1 \times 10^{6}$ cells in $1 \mathrm{x}$ binding buffer. $5 \mu \mathrm{L}$ of fluorochrome-conjugated Annexin $\mathrm{V}$ and 5 
$\mu \mathrm{L}$ Propidium lodide Staining dyes were added and incubated for 15 minutes at room temperature, $100 \mu \mathrm{L}$ of $1 \mathrm{x}$ binding buffer was added and analyzed by flow cytometry (BD Via, New Jersey, USA).

\section{Cell Cycle Assay}

Cell cycle analysis was performed using the BD Cycletest тм Plus DNA Reagent kit (BD Biosciences, New Jersey, USA) in accordance with the manufacturer's instructions. According to the kit protocol, $1 \times 10^{6}$ cells were seeded in the 6 -well plate for 24 hours and the cells were incubated with the plant extract at dose of $100 \mu \mathrm{g} / \mathrm{ml}$. After incubation, $250 \mu \mathrm{L}$ solution A was added and incubated in a lightfree environment for $10 \mathrm{~min}$. $200 \mu \mathrm{L}$ of solution $\mathrm{B}$ is added for 10 minutes, and $200 \mu \mathrm{L}$ of solution $C$ is added for 10 minutes in a protected environment at $+4{ }^{\circ} \mathrm{C}$. All these analyzes were performed by flow cytometry (BD Via, NJ, USA).

JC-1 staining for mitochondrial membrane potential (MMP, $\Delta \psi \mathrm{m}$ )

To detect changes in mitochondrial function induced by MMP. The mitochondrial membrane potential was measured by JC-1 dye $\left(5.5^{\prime}, 6.6^{\prime}\right.$-tetrachloro-1.1',3.3'-tetra ethyl imida carbo cyanine iodide) (BD ${ }^{\mathrm{TM}}$ Mito Screen, New Jersey, USA). $1 \times 10^{6}$ cells were seeded in the 6-well plate for 24 hours and the cells were incubated with the plant extract at dose of $100 \mu \mathrm{g} / \mathrm{ml}$. After incubation, JC-1 (1 $\mu \mathrm{g} / \mathrm{mL}$ ) was added and incubated for $15 \mathrm{~min}$ at $37^{\circ} \mathrm{C}$ in a dark environment. After incubation, cells were washed twice with $1 x$ wash solution. All these analyzes were performed by flow cytometry (BD Via, NJ, USA).

\section{Gene Expression}

All gene expression analyses were performed after treating plant extract with a dose of $100 \mu \mathrm{g} / \mathrm{mL}$ for $24 \mathrm{hr}$. Total RNA isolation was performed with miRNeasy mini-kit (Qiagen Hilden, Germany), and complementary DNA synthesis was done using the $\mathrm{RT}^{2}$ First strand kit (Qiagen Hilden, Germany) according to the kit procedure. RT-qPCR, Rotor-Gene $Q$ was performed on a Real Time PCR System (Qiagen Hilden, Germany) with QuantiTect SYBR Green PCR kit (Qiagen Hilden, Germany). qPCR protocol can be done at $95^{\circ} \mathrm{C}$ for $10 \mathrm{~min}$, followed by 40 cycles of $95^{\circ} \mathrm{C}$ for $15 \mathrm{~s}$, at $60{ }^{\circ} \mathrm{C}$ for $60 \mathrm{~s}$ and at $65^{\circ} \mathrm{C}$ for $1 \mathrm{~min}$. Each sample was studied in triplicate by using the primary series and GAPDH housekeeping gene. The gene expression was calculated using the $2^{\wedge}-\Delta \Delta C$ t (fold change) method in comparison with the controls, and the $p$ values were analyzed with GraphPad Prism 8 software. Primers were designed by using Primer blast on the National Center for Biotechnology Information website. All primers were determined to be $95-100 \%$ efficient and all showed only one dissociation peak. Sequences are listed in Table 1.

\section{Determination of Nitric oxide (NO) level with ELISA}

A total of $1 \times 10^{6} \mathrm{HL}-60$ cells were incubated in a 6 -well plate with plant extract $(100 \mu \mathrm{g} / \mathrm{mL})$ for $24 \mathrm{hrs}$. We harvested the incubated cells and used cold PBS for washing. Then, the cells were decomposed at $0^{\circ} \mathrm{C}$ and centrifuged at $4^{\circ} \mathrm{C}, 12.000 \times \mathrm{xg}$ for $10 \mathrm{~min}$. The absorbance was detected using a microplate reader (Thermo Scientific Multiskan GO, USA). A standard curve provided by the kit was used to calculate the activity.

Table 1. Primer sequences used in gene expression.

\begin{tabular}{|c|c|c|}
\hline Primer & Forward $\left(5^{\prime}-3^{\prime}\right)$ & Reverse(3'-5') \\
\hline CASPASE-3 & TGTCGGCATACTGTTTCAGCA & TGGCGAAATTCAAAGGATGGC \\
\hline CASPASE- 8 & TGGGAGAAGGAAAGTTGGACA & CGTTGATTATCTTCAGCAGGCTC \\
\hline CASPASE-9 & GCCCTGGCCTTATGATGTTTT & GCTGTTTCGGTGAAAGGGATTT \\
\hline BAX & GCTGACATGTTTTCTGACGGC & TTGAGCACCAGTTTGCTGGC \\
\hline $\mathrm{BCL}-2$ & TGACCCCACCGAACTCAAAG & GACTTCGCCGAGATGTCCA \\
\hline P53 & TAACAGTTCCTGCATGGGCG & ACCTCAAAGCTGTTCCGTCC \\
\hline P27 & ACCTGCAACCGACGATTCTT & GTCCATTCCATGAAGTCAGCG \\
\hline NFKB & ATCCATATTTGGGAAGGCCTGA & GGAAACGAAATCCTCTCTGTTTAGG \\
\hline PTEN & GCGGAACTTGCAATCCTCAG & GGTAACGGCTGAGGGAACTC \\
\hline LC3 & ATCATCGAGCGCTACAAGGG & AGAAGCCGAAGGTTTCCTGG \\
\hline BECLIN-1 & CGACTGGAGCAGGAAGAAG & TCTGAGCATAACGCATCTGG \\
\hline GAPDH & CCTGACCTGCCGTCTAGAAA & TGGGTGTCGCTGTTGAAGTC \\
\hline
\end{tabular}

\section{Statistical Analysis}

The distribution of data was controlled by the ShapiroWilk test. While Student- t-test was used for the groups with a normal distribution ( $p>0.05$ ), the Mann Whitney $U$ test was used to compare two groups without a normal distribution $(p<0.05)$. One-way ANOVA test was used to compare three or more groups with a normal distribution. SPSS 25 (SPSS, Inc, Chicago, IL) and GraphPad prism 8 (GraphPad Software, Inc, San Diego, USA) were used for statistical analysis $\left({ }^{*} p<0.05 ;{ }^{* *} p<0.01\right)$.

\section{Results}

\section{Anti-cancer activity of Urtica dioica $L$. extract on HL-60 cells}

HL-60 cells that was treated with Urtica dioica L. extract showed a remarkable suppression in cell proliferation at a dose of $100 \mu \mathrm{g} / \mathrm{mL}$ according to the results of MTT staining after 24 hours, and this decrease was statistically significant (Figure 1A). When the cell morphology between the groups was evaluated, it was observed that the cells were lysed and the number of cells decreased at a dose of $100 \mu \mathrm{g} / \mathrm{mL}$ compared to the cells treated with negative and DMSO (X20) (Figure 1B). According to the results of Annexin V/PI staining that we had conducted to determine its effect on cell death, it was found that cells died in a plant extract at a dose of $100 \mu \mathrm{g} / \mathrm{mL}$ (live: $5.69 \%$; early apoptotic: $5.8 \%$; late apoptotic: $42.76 \%$; necrotic: 45.75\%) (Figure 1C). According to the result of Propidium lodide (PI) staining that we had performed to determine the effect of Urtica dioica $L$. extract on the cell cycle, it was observed that the cells were arrested in the G0/G1 phase $(70.2 \%)$ at a dose of $100 \mu \mathrm{g} / \mathrm{mL}$ and the cell division was slowed down (Figure 1D). According to the results of JC-1 staining that we had done to determine the effect of $\mathrm{HL}-60$ cells on mitochondrial membrane potential, the mortality rate was found to be $18.9 \%$ and that was due to organelle loss at a dose of $100 \mu \mathrm{g} / \mathrm{mL}$ (Figure 1E). 


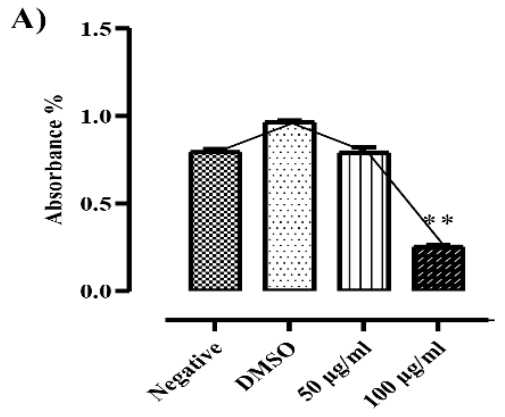

C)
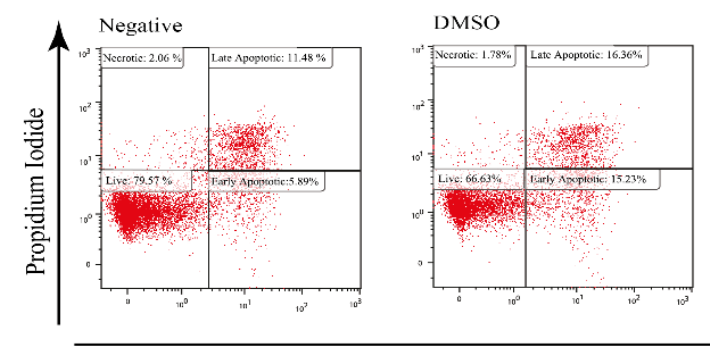

Annexin V

D)

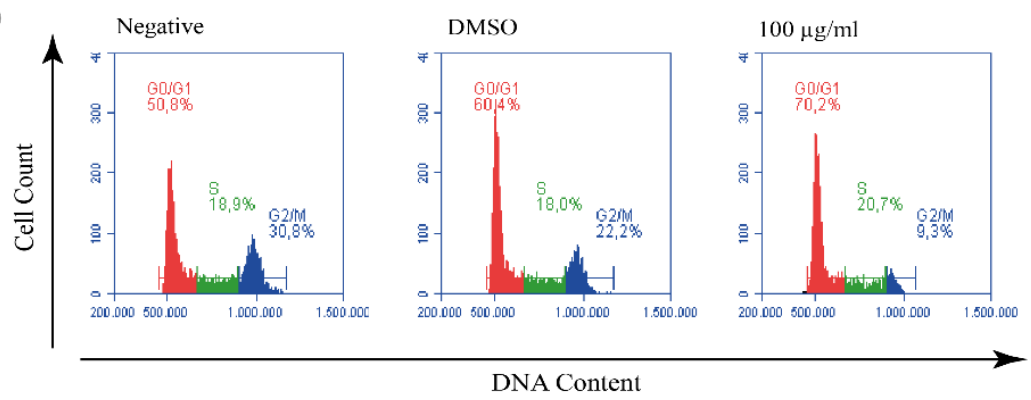

E)

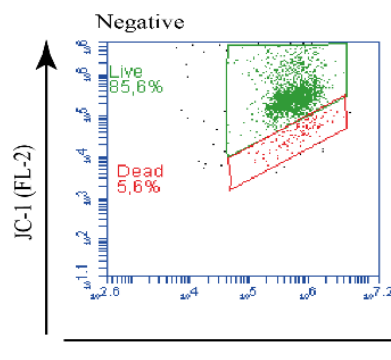

F)

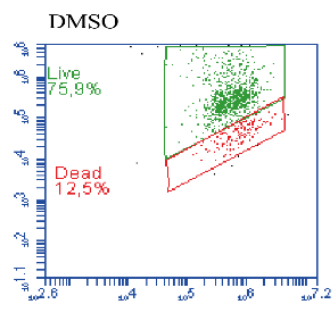

JC-1 (FL-1)

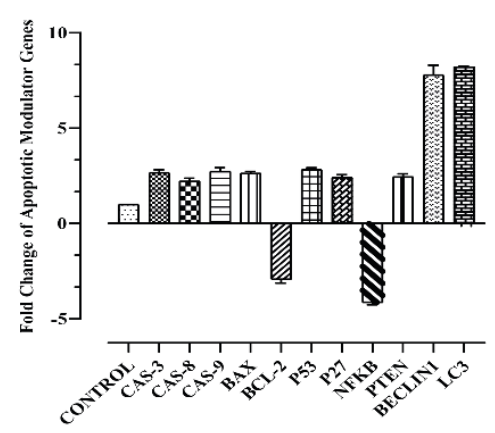

DMSO
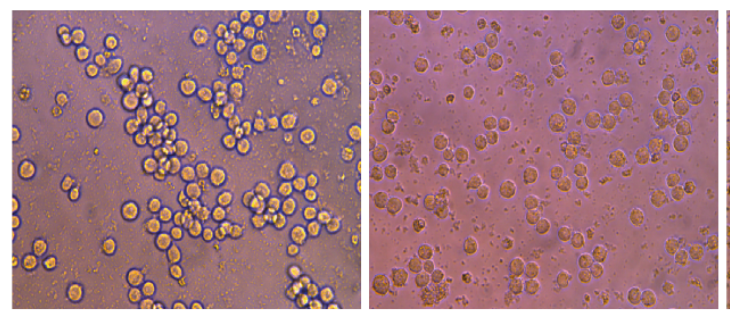

$100 \mu \mathrm{g} / \mathrm{ml}$

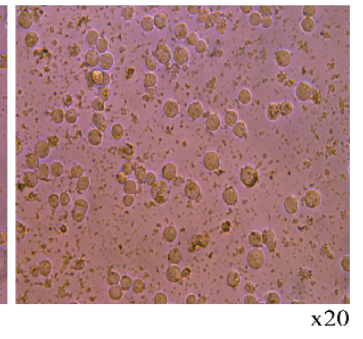

$\square$ Live

$\square$ Early Apoptotic

$\square$ Late Apoptotic

$\square$ Necrotic
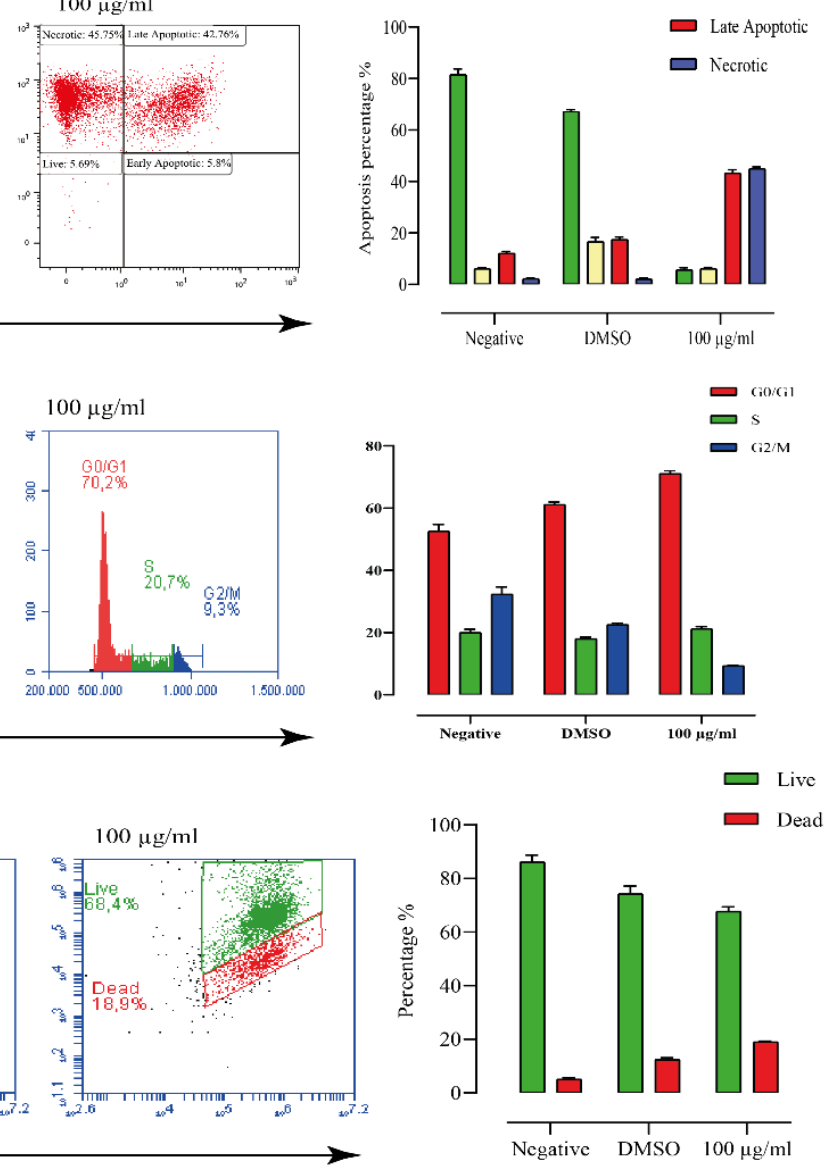

G)

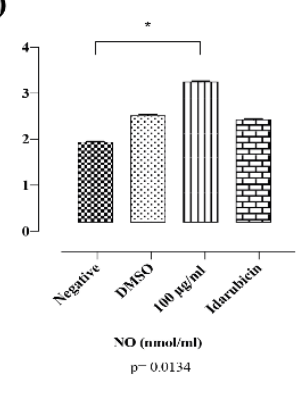

Figure 1. Effect of Urtica dioica L. extract on HL-60 cell line.

A. Graph of changing cell viability as a result of Urtica dioica L. extract application to HL-60 cells (Negative; DMSO (used during dissolution of the extract and its ratio in the extract was adjusted as 1/1000); 50 and 100 $\mathrm{gg} / \mathrm{mL}$ Urtica dioica L. extract). B. Changing cell morphological image after substance administration (X20). C. Annexin V/PI staining result after treatment of Urtica dioica L. extract. D. PI staining result showing the effect of Urtica dioica L. extract on cell division. E. JC-1 staining result showing mitochondrial membrane potential change. F. Graph showing the expression levels of genes involved in the apoptotic pathway and cell division check points. G. Measurement plots of NO levels after treatment of Urtica dioica L. extract. 
It has to be noted that P53 expression which is considered as a DNA damage marker and cell cycle checkpoint, has been found to be increased. In addition, the increase in pro-apoptotic BAX gene expression and the decrease in anti-apoptotic BCL-2 gene expression were determined as an improvement that apoptosis was triggered in the cell. It was also found that the expression of the apoptotic cascade regulator of CAS-3, 8 and 9 genes was increased. The increase in P27 gene expression working with P53 at the cell division and control point indicates that apoptosis is triggered by halting cell division in the presence of DNA damage. NF-KB prevents cell death which is caused by tumor necrosis factor (TNF) and the other genotoxic attacks by directly inducing anti-apoptotic target genes. According to the results of our study, the decrease in BCL-2 and NF-kB gene expressions leads to make cell death to be markedly observed moreover the increase in PTEN expression confirms these results.

BECLIN1 and BCL-2 expression levels play a role in controlling the mechanism that regulates the change in cell death pathway type I and II. The BECLIN1 level was responsible for the decrease that occurred in cells as cancerous and the poor prognosis of the cancer. It was also noted that BECLIN1 and LC3 expressions were increased in $\mathrm{HL}-60$ cells treated with Urtica dioica L. extract and BCL2 expression was decreased (Figure 1F). After the treatment of Urtica dioica L. extract, Nitric oxide (NO) level was found to be increased significantly at the effective dose (Figure 1G).

\section{Discussion}

Cancer has been described as the disease of the 21st century with a few effective treatment options. The most commonly used treatment methods, chemotherapy; radiotherapy, hormone therapy, surgical treatments and most recently, nanotechnology-based applications and gene silencing methods are found to be used (13). The inadequacy and side effects of these used treatment methods have paved the way for the development of alternative treatment strategies. In particular, there is a need for a specific anti-cancer treatment tool that will effectively halt the initiation and progression of cancer, with few side effects and high cytotoxicity (14). As a traditional treatment method, herbal compounds are used in the production of modern anti-cancer drugs as well as being a valuable source producing agents that inhibit the proliferation of cancer cells $(15,16)$. The used herbal compounds (phytochemicals) in treatment of cancer consist of biologically active substances such as carotenoids, flavonoids, anthocyanins or terpenoids. These active substances are used today to extract chemical agents with important pharmacological effects. Some of the compounds that were obtained from plants and were used as neoplastic agents; irinotecan, vincristine, etoposide and paclitaxel (17). In general, the mechanism of action of these plant-based chemicals works by controlling cell division, differentiation and regulating the apoptotic mechanism in cells whose structure is disrupted. In some of the recent carried out studies, the combined treatment method has been tried to obtain simultaneous treatment; It is aimed to increase the effectiveness of the treatment by using a traditional chemotherapeutic drug and a natural compound or two/more natural agents. Another objective for this method is to increase the sensitivity of cancer cells to chemotherapeutic drugs by targeting more than one metabolic pathway and reducing the development of resistance to anti-cancer drugs. A study was conducted by Mohammad et al. (2016) (18) they emphasized the importance of a combined approach and found that by combining Urtica dioica $L$. extract with paclitaxel reduces paclitaxel resistance in breast cancer cells, they sensitized the cells to the drug and increased the effectiveness of the neoplastic agent. In addition to the combined treatment proposition, only plant extract-based treatment strategies occupy a wide place in the literature. As a common result of the studies conducted in this field, it has been determined that herbal therapy can help preventing the development of cancer as well as positively affects the healing process by increasing the survival rate of patients (19).

In this study, we evaluated the effects of the water extract that was prepared using the leaves and stems of Urtica dioica plant targeting $\mathrm{HL}-60$ cell proliferation and apoptotic mechanism. It has been determined that Urtica dioica plant has anticancer activity by studies conducted in different solvents and different cell lines. The first study conducted in this context was conducted by Nahata et al. in 2012. Anticancer activity experiments were carried out on 7 different cancer lines (PC-3, DU-145, A-549, MCF-7, IGR-OV-1, CoLo-205 and IMR-3) of the fraction prepared in 3 different solvents (petroleum ether, ethanolic, and aqueous) using Urtica dioica plant. As a result of the study, the anti-cancer activity of the Urtica dioica L. plant was not detected (20). In 2016, Mohammedi et al. in the study conducted by, MDA-MB-468 breast cancer cells were treated with Urtica dioica extract and paclitaxel formed in the cells, these two agents made the cells sensitive to the drug by reducing the drug resistance. Also it can lead to death of the cells by reducing cell proliferation (18). In 2017, Turk et al. In the study conducted by Urtica dioica root extract, the cytotoxic effect of the hemostatic agent (Ankaferd hemostat) that was prepared using five plants, it was conducted on melanoma cell line and it was shown that the drug had a negative effect on cell viability with increasing concentration and incubation time (21). In this study, we found that Urtica dioica water extract reduced $\mathrm{HL}-60$ cell proliferation $(100 \mu \mathrm{g} / \mathrm{mL})$ and altered morphologically (Figure 1A-B). According to Annexin V/PI staining results, we determined the rate of cell death as $48.56 \%$ compared to the negative group (Figure $1 \mathrm{C}$ ). 
These obtained results were compatible with the literature. According to a recent study, Urtica dioica $L$. methanol extract was found to induce apoptosis by exerting anti-proliferative effect in HCT-116 and HEPG-2 cells (22). As stated by the results of PI staining that were done to evaluate the effects on the cell cycle, we found that cell division was arrested in the G0/G1 phase (70.2\%) (Figure 1D). We tested the effect on mitochondrial membrane potential using the JC-1 staining method and found that $18.9 \%$ of the mitochondrial membrane structure was disrupted in the group to which we applied the extract (Figure $1 \mathrm{E}$ ). We tested the effects of these obtained data by flow cytometry method on apoptotic mediator genes with RT-PCR method. It was found that the expression of the BAX gene was increased. BAX gene is one of the apoptotic pathway mediator genes, a member of the impaired mitochondrial membrane marker (23) and pro-apoptotic gene family. Additionally, the expression of the antiapoptotic gene BCL-2 was decreased significantly (rate of increase and decrease was evaluated on the basis of the two multiples and expressed fold change). The markedly increased P53 expression indicates the presence of DNA damage, meanwhile the increase in CAS-3, 8 and 9 expressions indicate that the apoptosis pathway of the cells is triggered. The increase in both the expression of PTEN (24) and a tumor suppressor gene (that regulates cellular metabolism, growth and survival mechanisms), indicates a decrease in cell proliferation and this result is correlated with cell cycle analyses. NF-kB prevents cell death caused by tumor necrosis factor (TNF) and other genotoxic attacks by directly inducing anti-apoptotic target genes (25). According to the results of our study, it was found that the decrease in BCL-2 and NF-KB gene expressions caused cell death and we emphasized the accuracy of these results by increasing PTEN gene expression. The cyclin-dependent kinase inhibitor P27 (KIP1) is a factor that inhibits cell cycle progression using specific molecular mechanisms. It also works in combination with P53 in the regulation of cell differentiation and apoptosis (26). In our study, we found that by increasing (P27) in correlation with P53, they have an inhibitory effect on cell division in the presence of DNA damage. BECLIN1 and BCL-2 expression levels play a role in the mechanism regulating autophagic-apoptotic change $(27,28)$. In addition, the decrease in BECLIN1 level has been associated with cancer pathogenesis and poor prognosis $(29,30)$. It was found that BECLIN1 and LC3 expressions were increased in HL60 cells treated with Urtica dioica L. extract and BCL-2 expression, was decreased (Figure 1F). Nitric oxide (NO) is a free radical gas with complex and pleiotropic biological activity that plays a key role in various physiological and pathological processes $(31,32)$. It has been stated that unregulated NO synthesis (Figure 1G) contributes to the pathophysiology of many diseases, including cancer (33). The scarcity or abundance of NO in cancer cells is a com- plex process in which pro-apoptotic gene activation or inactivation occurs in cells $(32,34,35)$.

\section{Conclusions}

In our study, the NO increases in HL-60 cells treated with Urtica dioica $L$. extract which caused a series of apoptotic gene activation. Our findings support this output. The increased apoptotic cell percentage, increase in cell involvement in the G0/G1 phase, increase in the expression of genes involved in the P53-CASPASE cascade, and decrease in NF-KB, BCL-2 gene expressions are considered be to perceivable evidence that triggers apoptosis by increasing NO levels.

Abbreviations: APL: Acute Promyelocytic Leukemia; AML: Acute Myeloid Leukemia; ATRA: All-Trans Retinoic Acid; HL 60: Human Promyelocytic Leukemia Cell Line

Ethical Approval: This article does not contain any studies with human or animal subjects performed by the any of the authors.

\section{Author Contributions:}

Concept: E.T., I.K., K.S.

Literature Review: E.T.

Design : E.T., I.K.

Data acquisition: E.T., O.Y., Y.A

Analysis and interpretation: E.T.

Writing manuscript: E.T.

Critical revision of manuscript: E.T.

Conflict of Interest: The authors have no conflicts of interest to declare.

Financial Disclosure: Authors declared no financial support.

\section{References}

1. Jalili $M$, Salehzadeh-Yazdi $A$, Mohammadi S, Yaghmaie $M$, Ghavamzadeh A, and Alimoghaddam K. Meta-Analysis of Gene Expression Profiles in Acute Promyelocytic Leukemia Reveals Involved Pathways. Int J Hematol Oncol Stem Cell Res. 2017; 11(1): 1-12.

2. Ohno R, Asou N, and Ohnishi K. Treatment of acute promyelocytic leukemia: strategy toward further increase of cure rate. Leukemia. 2003; 17(8): 1454-63.

3. Lo-Coco F and Hasan SK. Understanding the molecular pathogenesis of acute promyelocytic leukemia. Best Pract Res Clin Haematol. 2014; 27(1): 3-9.

4. Mohammadi A, Mansoori B, Aghapour M, Shirjang S, Nami S, Baradaran $B$. The Urtica dioica extract enhances sensitivity of paclitaxel drug to MDA-MB-468 breast cancer cells. Biomed Pharmacother. 2016; 83: 835-42.

5. Mohammadi A, Mansoori B, Aghapour M, Baradaran B. Urtica dioica dichloromethane extract induce apoptosis from intrinsic pathway on human prostate cancer cells (PC3). Cell Mol Biol (Noisy-le-grand). 2016; 62(3): 78-83.

6. Mohammadi A, Mansoori B, Goldar S, Shanehbandi D, Khaze $V$, Mohammadnejad L, et al. Effects of Urtica dioica dichloromethane extract on cell apoptosis and related gene expression in human breast cancer cell line (MDA-MB-468). Cell Mol Biol (Noisy-le-grand). 2016; 62(2): 62-7.

7. Bnouham M, Merhfour FZ, Ziyyat A, Aziz M, Legssyer A, Mekhfi H. Antidiabetic effect of some medicinal plants of Orien- 
tal Morocco in neonatal non-insulin-dependent diabetes mellitus rats. Hum Exp Toxicol. 2010; 29(10): 865-71.

8. El Haouari M, Bnouham M, Bendahou M, Aziz M, Ziyyat A, Legssyer $A$, et al. Inhibition of rat platelet aggregation by Urtica dioica leaves extracts. Phytother Res. 2006; 20(7): 568-72.

9. Konrad L, Muller HH, Lenz C, Laubinger $\mathrm{H}$, Aumuller $\mathrm{G}$, Lichius JJ. Antiproliferative effect on human prostate cancer cells by a stinging nettle root (Urtica dioica) extract. Planta Med. 2000; 66(1): 44-7.

10. Testai L, Chericoni S, Calderone V, Nencioni G, Nieri P, Morelli I, et al. Cardiovascular effects of Urtica dioica L. (Urticaceae) roots extracts: in vitro and in vivo pharmacological studies. J Ethnopharmacol. 2002; 81(1): 105-9.

11. Mansoori B, Mohammadi A, Shir Jang S, Baradaran B. Mechanisms of immune system activation in mammalians by small interfering RNA (siRNA). Artif Cells Nanomed Biotechnol. 2016; 44(7): 1589-96.

12. Mansoori B, Sandoghchian Shotorbani S, and Baradaran B. RNA interference and its role in cancer therapy. Adv Pharm Bull. 2014; 4(4): 313-21.

13. Roy $P$, Saikia B. Cancer and cure: a critical analysis. Indian journal of cancer. 2016; 53(3): 441.

14. Esposito S, Bianco A, Russo R, Di Maro A, Isernia C, Pedone $P V$. Therapeutic perspectives of molecules from Urtica dioica extracts for cancer treatment. Molecules. 2019; 24(15): 2753.

15. Demiryürek AT, Saracaloglu A, Temiz E, Demiryürek $S$, Sener B. Investigation of the Apoptotic Effects of Pistacia vera Nut Skin Methanol Extract on Human Gastric Cancer Cell Line HGC-27. in Multidisciplinary Digital Publishing Institute Proceedings. 2018. 16. Yumrutaş Ö, Pehlivan M, Güven C, Bozgeyik I, Bozgeyik E, Yumrutaş $P$, et al. Investigation of cytotoxic effect of salvia pilifera extracts and synthetic chlorogenic and caffeic acids on DU145 prostate cancer cells line. Tarim ve Doga Dergisi. 2018; 21(2): 141.

17. Nobili S, Lippi D, Witort E, Donnini M, Bausi L, Mini E, et al. Natural compounds for cancer treatment and prevention. Pharmacological research. 2009; 59(6): 365-78.

18. Mohammadi A, Mansoori B, Aghapour M, Shirjang S, Nami $S$, Baradaran $B$. The Urtica dioica extract enhances sensitivity of paclitaxel drug to MDA-MB-468 breast cancer cells. Biomedicine \& Pharmacotherapy. 2016; 83: 835-42.

19. Rejhová A, Opattová A, Čumová A, Slíva D, Vodička P. Natural compounds and combination therapy in colorectal cancer treatment. European journal of medicinal chemistry. 2018; 144: 58294.

20. Nahata A, Saxena A, Suri N, Saxena AK, Dixit VK. Sphaeranthus indicus induces apoptosis through mitochondrial-dependent pathway in $\mathrm{HL}-60$ cells and exerts cytotoxic potential on several human cancer cell lines. Integrative cancer therapies. 2013; 12(3): 236-47.

21. Turk S, Malkan UY, Ghasemi M, Hocaoglu H, Mutlu D, Gunes $G$, et al. Growth inhibitory activity of Ankaferd hemostat on primary melanoma cells and cell lines. SAGE open medicine. 2017; 5: 205.

22. Kardan M, Rafiei A, Golpour M, Ebrahimzadeh MA, AkhavanNiaki H, Fattahi S. Urtica dioica Extract Inhibits Cell Proliferation and Induces Apoptosis in HepG2 and HTC116 as Gastrointestinal Cancer Cell Lines. Anti-Cancer Agents in Medicinal Chemistry (Formerly Current Medicinal Chemistry-Anti-Cancer Agents). 2020; 20(8): 963-69.

23. Bock FJ, Tait SW. Mitochondria as multifaceted regulators of cell death. Nature reviews Molecular cell biology. 2020; 21(2):
85-100.

24. Chen C-Y, Chen J, He L, Stiles BL. PTEN: tumor suppressor and metabolic regulator. Frontiers in endocrinology. 2018; 9: 338.

25. Mercogliano MF, Bruni S, Elizalde PV, Schillaci R. Tumor necrosis factor $\alpha$ blockade: an opportunity to tackle breast Cancer. Frontiers in oncology. 2020; 10(1):12-17.

26. Abbastabar M, Kheyrollah M, Azizian K, Bagherlou N, Tehrani SS, Maniati M, et al. Multiple functions of p27 in cell cycle, apoptosis, epigenetic modification and transcriptional regulation for the control of cell growth: a double-edged sword protein. DNA repair. 2018; 69: 63-72.

27. Marquez RT , Xu L. Bcl-2: Beclin 1 complex: multiple, mechanisms regulating autophagy/apoptosis toggle switch. American journal of cancer research. 2012; 2(2): 214.

28. Bostancıklıoglu M. An update on the interactions between Alzheimer's disease, autophagy and inflammation. Gene. 2019; 705: 157-66.

29. Mutlu H, Mutlu S, Bostancıklıoğlu M. Profiling of AutophagyAssociated microRNAs in the Osteosarcoma Cell Line of U2OS. Anti-Cancer Agents in Medicinal Chemistry. 2020; 2021(21): 17.

30. Liu C, Xu P, Chen D, Fan X, Xu Y, Li M, et al. Roles of autophagy-related genes Beclin- 1 and LC3 in the development and progression of prostate cancer and benign prostatic hyperplasia. Biomedical reports. 2013; 1(6): 855-60.

31. Choudhari SK, Chaudhary M, Bagde S, Gadbail AR, and Joshi V. Nitric oxide and cancer: a review. World journal of surgical oncology. 2013; 11(1): 1-11.

32. Olson SY, Garbán HJ. Regulation of apoptosis-related genes by nitric oxide in cancer. Nitric Oxide. 2008; 19(2): 170-76.

33. Harada K, Kawaguchi S-I, Tomitaro O, Yoshida H, and Sato M. Overexpression of iNOS gene suppresses the tumorigenicity and metastasis of oral cancer cells. in vivo. 2004; 18(4): 449-55.

34. Weiming $X$, Liu LZ, Loizidou M, Ahmed M, Charles IG. The role of nitric oxide in cancer. Cell research. 2002; 12(5): 311-20. 35. Kim HH , Kim K. Enhancement of TNF- $\alpha$-mediated cell death in vascular smooth muscle cells through cytochrome c-independent pathway by the proteasome inhibitor. FEBS letters. 2003; 535(1-3): 190-94. 